\title{
Co-Selection of Heavy Metal and Antibiotic Resistance in Soil Bacteria from Agricultural Soils in New Zealand
}

\author{
Ali Heydari ${ }^{1}$, Nick D. Kim ${ }^{1}{ }^{\circledR}$, Jacqui Horswell ${ }^{1}$, Gerty Gielen ${ }^{2}$, Alma Siggins ${ }^{3}$, Matthew Taylor ${ }^{4}\left({ }^{\circ}\right.$, \\ Collette Bromhead ${ }^{1}$ and Barry R. Palmer ${ }^{1, *(1)}$ \\ 1 School of Health Sciences, Massey University, Wellington 6021, New Zealand; \\ Aliheydari781@gmail.com (A.H.); N.Kim@massey.ac.nz (N.D.K.); Jacqui.Horswell@mpi.govt.nz (J.H.); \\ C.Bromhead@massey.ac.nz (C.B.) \\ 2 Scion, Tìtokorangi Drive, Rotorua 3010, New Zealand; Gerty.Gielen@scionresearch.com \\ 3 Civil Engineering and Ryan Institute, National University of Ireland, H91 TK33 Galway, Ireland; \\ Alma.Siggins@nuigalway.ie \\ 4 Waikato Regional Council, Hamilton 3240, New Zealand; Matthew.Taylor@waikatoregion.govt.nz \\ * Correspondence: B.Palmer@massey.ac.nz
}

check for updates

Citation: Heydari, A.; Kim, N.D.; Horswell, J.; Gielen, G.; Siggins, A.; Taylor, M.; Bromhead, C.; Palmer, B.R. Co-Selection of Heavy Metal and Antibiotic Resistance in Soil Bacteria from Agricultural Soils in New

Zealand. Sustainability 2022, 14, 1790. https://doi.org/10.3390/su14031790

Academic Editors: Silvia Tabacchioni and Christophe Waterlot

Received: 14 December 2021

Accepted: 2 February 2022

Published: 4 February 2022

Publisher's Note: MDPI stays neutral with regard to jurisdictional claims in published maps and institutional affiliations.

Copyright: (c) 2022 by the authors. Licensee MDPI, Basel, Switzerland. This article is an open access article distributed under the terms and conditions of the Creative Commons Attribution (CC BY) license (https:// creativecommons.org/licenses/by/ $4.0 /)$.

\begin{abstract}
Accumulation of trace elements (including heavy metals) in soil from usage of superphosphate fertilisers induces resistance of soil bacteria to trace elements of environmental concern (TEoEC) and may co-select for resistance to antibiotics $(\mathrm{Ab})$. This study aimed to investigate selection of co-resistance of soil bacteria to $\mathrm{Cd}, \mathrm{Zn}$ and $\mathrm{Hg}$, and $\mathrm{Ab}$ in soils with varied management histories. Genetic diversity of these bacteria and horizontal transfer of $\mathrm{Cd}$ resistance genes ( $c a d A$ and $c z c A$ ) were also investigated. Soils with either pastoral and arable management histories and either high levels of $\mathrm{Cd}$ and $\mathrm{Zn}$, or indigenous bush with background levels of these TEoEC from the Waikato region, New Zealand were sampled. Plate culturing with a range of TEoEC and Ab concentrations, Pollution Induced Community Tolerance (PICT) assay, antibiotic sensitivity, terminal restriction fragment length polymorphism (TRFLP) and horizontal gene transfer (HGT) analyses were employed to investigate co-selection of TEoEC and Ab resistance. Higher levels of bacterial resistance to TEoEC and $\mathrm{Ab}$ correlated with higher levels of TEoEC in soil. Bacterial community structures were altered in soils with high TEoEC levels. Cd resistance genes were transferred from donor bacterial isolates, to recipients and the transconjugants also had resistance to $\mathrm{Zn}$ and/or $\mathrm{Hg}$ and a range of $\mathrm{Ab}$.
\end{abstract}

Keywords: trace elements; heavy metal resistance; antibiotic resistance; bacteria; soil; co-selection; PICT; TRFLP; horizontal gene transfer

\section{Introduction}

Most trace elements have a fundamental role in the life processes of microorganisms and higher organisms and act as essential elements in the environment. Trace elements (TEs) of environmental concern (TEoEC) including cadmium (Cd), zinc $(\mathrm{Zn})$ and mercury $(\mathrm{Hg})$ can be added to the environment by a variety of different human-related activities or natural processes [1]. Some TEs, such as $\mathrm{Cd}, \mathrm{Hg}$, silver $(\mathrm{Ag})$, and lead $(\mathrm{Pb})$, have no known beneficial role, and their cations (e.g., $\mathrm{Cd}^{2+}$ and $\mathrm{Hg}^{2+}$ ) can form potentially harmful complexes [2]. Some other metals, e.g., cobalt (Co), $\mathrm{Zn}$ and copper ( $\mathrm{Cu}$ ), are micronutrients and considered necessary elements for cellular metabolism and other processes in life. These can also be harmful at high concentrations [3]. For example, $\mathrm{Zn}$ is involved in stabilizing many enzymes as well as RNA and DNA via electrostatic forces [4]; however, in high concentrations these ions can have toxic effects, by producing complex compounds in cells. The presence of high concentrations of non-essential metals in cells can be detrimental to cell functioning, as the non-essential metals may have a higher binding affinity to thiol groups or oxidised organic products and displace essential metals [5]. 
Contamination of soil, by TEoECs is an important issue due to potential impacts on ecosystem functions [6]. Sources include the discharge of agricultural chemicals, fertilisers, animal manure and other wastes applied to land with subsequent transfer to aquatic environments [5]. Accumulation of such contaminants including $\mathrm{Cu}, \mathrm{Hg}, \mathrm{Pb}, \mathrm{Zn}$ and $\mathrm{Cd}$ in the soil environment potentially endangers human and animal health and may trigger resistance to $\mathrm{Ab}$ [7]. Studies have linked exposure to heavy metals (HM) to Ab resistance through mechanisms of co-resistance (different resistance determinants on shared gene elements), cross-resistance (genes encoding resistance to both TEoEC and $\mathrm{Ab}$ ) and shared regulatory responses to TEoEC and Ab exposure, like biofilm induction [8]. Accumulation of TEoECs in soil is considered an emerging issue endangering human and animal health $[9,10]$.

Bioavailability and toxicity of trace elements in the environment are influenced by soil composition - particularly the content and nature of organic matter, hydrated metal oxides, and clay minerals - and environmental conditions, including $\mathrm{pH}$ and redox potential. For cationic metals, lower $\mathrm{pH}$ is associated with increased mobility, and low oxygen (reducing conditions) can result in an increase in metal release through partial dissolution of amorphous metal oxides [3].

Recent studies have shown that TEoEC resistance and $\mathrm{Ab}$ resistance can be selected simultaneously by microorganisms in TEoEC-contaminated ecosystems [11] and those with other contaminants [12]. This underlines the importance of preventing the accumulation of TEoEC in the environment. The co-selection of TEoEC and Ab resistance is a potentially serious health concern in terms of both human and animal health. This could also cause economic burdens on the livestock industry $[13,14]$.

New Zealand's agricultural soils are subject to a range of contaminant inputs, of which inorganic contaminants in phosphate fertilisers and animal remedies are of special interest due to their capacity to accumulate over time [15]. The application of superphosphate fertiliser leads to elevated levels of some HMs in agricultural soils, especially Cd $[7,16,17]$. The use of animal remedies and pesticides containing $\mathrm{Zn}$ has resulted in raised levels of $\mathrm{Zn}$ in these soils to $60 \mathrm{mg} \mathrm{kg}^{-1}[18,19]$.

$\mathrm{Cd}$ concentrations in soils of dairy farms in the Waikato region of New Zealand are on average five times higher than their natural background levels after seven decades of accumulation from phosphate fertilisers $[16,20]$. The national average concentration of $\mathrm{Cd}$ in soil in New Zealand is about $0.35 \mathrm{mg} \mathrm{kg}^{-1}$. This concentration of $\mathrm{Cd}$ differs with land use, with $0.43 \mathrm{mg} \mathrm{kg}^{-1}$ for pastoral soils, $0.24 \mathrm{mg} \mathrm{kg}^{-1}$ for arable soils, and $0.16 \mathrm{mg} \mathrm{kg}^{-1}$ for indigenous forest (background) soils; the latter do not receive fertiliser application [21]. Average $\mathrm{Zn}$ concentrations have doubled in pastoral and arable soils during the last two-three decades through the widespread use of $\mathrm{Zn}$ in agricultural chemicals (e.g., as a preventative for the fungal disease facial eczema in sheep and cattle) [19]. Average figures also obscure the heterogeneity in soils and the fact that some areas have accumulated more $\mathrm{Cd}$ or $\mathrm{Zn}$ than others. The average concentration of $\mathrm{Zn}$ in Waikato soils was $60 \mathrm{mg} \mathrm{kg}^{-1}$, but $11 \%$ of farms in this region had $\mathrm{Zn}$ concentrations exceeding $100 \mathrm{mg} \mathrm{kg}^{-1}$. This concentration $\left(100 \mathrm{mg} \mathrm{kg}^{-1}\right)$, and $1 \mathrm{mg} \mathrm{kg}^{-1}$ for $\mathrm{Cd}$, have been suggested as guideline thresholds for protection of soil microbial processes [22] and potential to impact on dietary levels [23], respectively. Hg levels in Waikato soils are very low $(>0.2 \mathrm{mg} / \mathrm{Kg})$ and primarily from natural sources like volcanism. The high levels of $\mathrm{Cd}$ and $\mathrm{Zn}$ in Waikato soils may lead to resistance to TEoEC and subsequent co-selection for Ab resistance in these soils bacteria $[24,25]$.

Horizontal Gene Transfer (HGT) plays an important role in the evolutionary changes of resistance to antimicrobials and TEoEC. The most common mechanisms of HGT in prokaryotes are conjugation, transformation, transposition and transduction [26].

The co-occurrence of resistance to these elements and $\mathrm{Ab}$ in soils from TEoEC contaminated areas is poorly understood. In this study, our primary hypothesis was that selection for both $\mathrm{Cd}, \mathrm{Zn}$ and $\mathrm{Hg}$, and $\mathrm{Ab}$ resistance would occur in soils contaminated with TEoECs. This also allowed us to test the secondary hypothesis that the levels of resistance (as measured by minimum inhibitory concentrations [MICs] and $\mathrm{EC}_{50}$ levels 
for TEoECs and Abs) might be higher on average in isolates from sites with contaminated soils, compared to isolates from background uncontaminated soil. A third hypothesis was that some bacterial taxonomic groups would be better able to adapt to a soil environment contaminated with TEoECs and this would result in differences in bacterial operational taxonomic unit profiles between sites with significantly different levels of TEoEC contamination. Our fourth hypothesis was that at least some TEoECR and/or AbR would be due to pre-existing resistance genetic elements, amplified and/or mobilized within the microbial biosphere, not just due to de novo mutations conferring resistance.

We aimed to gain a further understanding of TEoEC resistance (TEoECR) and antibiotic resistance $(\mathrm{AbR})$ co-selection by comparing ratios of TEoECR and AbR bacteria to total colony forming units (cfu) in samples from sites with pastoral and arable farming land use histories with elevated soil TEoEC levels. Levels of resistance for both selected individual isolates and consortia from each site were determined. We examined potential differences in bacterial community structure using Terminal Restriction Fragment Length Polymorphism (TRFLP) assay [27], and a sample of isolates were identified using 16S rDNA sequencing. We investigated if resistance genes were mobilized to new bacterial hosts via conjugation assays of HGT of Cd resistance genes. The identity of the bacteria carrying mobilizable $\mathrm{Cd}$ resistant genes was determined by $16 \mathrm{~S}$ rDNA sequencing.

\section{Materials and Methods}

\subsection{Soil Samples}

Three sets of soil samples, with each set including samples originating from pastoral, arable and indigenous forest (background, control) sites were collected from the Waikato region of New Zealand based on standard soil sampling protocols [28]. Samples were collected from the upper soil horizon at $0-10 \mathrm{~cm}$ depth and aggregated to provide sufficient mass for sample analysis. Sampling was performed from February 2014 to June 2015. A total of five different rural properties were sampled (Table 1), drawn from sites that make up the Waikato Regional Council's Regional Soil Quality Monitoring Programme [29]. The sampling sites from agricultural properties were chosen from those with regular inputs of $\mathrm{Cd}$ and $\mathrm{Zn}$ due to usage of fertilisers and animal remedies. Input rates of $\mathrm{Cd}$ from fertilisers in Waikato for the approximate period 1945-2005 (six decades), based on loading estimates and observed soil values have been estimated as $0.006-0.007 \mathrm{mg} \mathrm{kg}^{-1} \mathrm{yr}^{-1}$ [30]. The annual amount of phosphorus applied to New Zealand soil as fertiliser peaked at 219,000 tonnes in 2005, but has reduced to an annual application of $\sim 150,000$ tonnes per year over the subsequent decade (155,000 tonnes in 2015) [31].

Table 1. Waikato region soil sampling sites sampled for this study.

\begin{tabular}{cccccc}
\hline Samples & Acronym & $\begin{array}{c}\text { Date } \\
\text { Sampled }\end{array}$ & $\begin{array}{c}\text { Indigenous } \\
\text { Forest Site }\end{array}$ & Arable Site & Pasture Site \\
\hline 1st sample set & WRSS1 & February 2014 & EW-73 & EW-85 & EW-69 \\
2nd sample set & WRSS2 & August 2014 & EW-73 & EW-86 & EW-135 \\
3rd sample set & WRSS3 & June 2015 & EW-73 & EW-85 & EW-69 \\
\hline
\end{tabular}

The soil for all samples was Patumahoe Clay Loam, classified as a typic Orthic Granular Soil in the New Zealand soil classification [32], and as a Ferralsol in the World Reference Base for Soil Resources [33]. Pastoral soil samples were collected from sheep and cattle farming sites EW-69 and EW-135. The arable cropping soil samples (sites EW-85 and EW-86) were from sites used in vegetable, potato and onion cropping for about 100 years. Both arable cropping and pastoral sites have received regular inputs of products containing TEoEC, (e.g., superphosphate fertilisers). Background samples were collected from site EW-73, a reserve covered in indigenous forest for $>100$ years, that has not received any inputs of products containing TEoEC. Physicochemical properties of soil samples were assessed by the methodology described in Table S1 (Supplementary Material). 


\subsection{Plate Culture}

Soil samples were sieved (aperture $=5 \mathrm{~mm}$ ) to remove large debris [34] and dry weight determined [35]. Soil samples (10 g, dry weight) were added to a $200 \mathrm{~mL}$ bottle containing sterile $1 \mathrm{X}$ phosphate buffered saline (PBS) $(\mathrm{pH}=7.0)$, and shaken at $200 \mathrm{rpm}$ at $4{ }^{\circ} \mathrm{C}$ for $1 \mathrm{~h}$. Serial dilutions were prepared with 1 X PBS diluent in sterile $50 \mathrm{~mL}$ glass bottles washed with $50 \%$ nitric acid, and aliquots were plated on R2A agar and incubated for up to 14 days at $25{ }^{\circ} \mathrm{C}$ [36]. Cycloheximide was dissolved in DMSO and filter sterilized, then added to the media (final concentration of $100 \mu \mathrm{g} \mathrm{mL} \mathrm{m}^{-1}$ ) to prevent the growth of fungi and yeasts [36].

$\mathrm{Cd}, \mathrm{Zn}$ and $\mathrm{Hg}$ and $\mathrm{Ab}$ (tetracycline (Tc), chloramphenicol $(\mathrm{Cm})$, erythromycin (Ery), carbenicillin $(\mathrm{Cb})$, and ampicillin (Amp) were added to R2A Agar plates using stock solutions of TEoEC ( $\mathrm{Ab}$ addition at $\sim 37^{\circ} \mathrm{C}$ ). The $\mathrm{Ab}$ were selected from different $\mathrm{Ab}$ classes. Final TEoEC ion concentrations were $0.1,0.01$ and $0.001 \mathrm{mM}$ for $\mathrm{CdCl}_{2}$ and $\mathrm{HgCl}_{2}$, and 1, 0.1 and $0.01 \mathrm{mM}$ for $\mathrm{ZnSO}_{4}$. Final concentrations of 20, 100 and $200 \mu \mathrm{g} \mathrm{mL}^{-1}$ of each $\mathrm{Ab}$ (dissolved in DMSO and sterilised by $0.45 \mu \mathrm{m}$ syringe filter) were used as media additives. These concentrations bracketed the average soil concentrations of the TEoEC over three orders of magnitude, and ranged an order of magnitude above the threshold for AbR in soil bacteria is defined as growth at $20 \mu \mathrm{g} \mathrm{mL}^{-1}$ by the EUCAST ECOFF classification [37].

\subsection{Minimum Inhibitory Concentration (MIC) and EC50 Determination}

MICs were determined by broth microdilution analysis for $\mathrm{Cd}, \mathrm{Zn}$ and $\mathrm{Hg}$ and the five $\mathrm{Ab}$ with $n=900$ selected bacterial isolates from each soil set (total $n=3600$ ). These isolates were selected based on various colony morphologies on the plates containing $\mathrm{Cd}$ $(1 \mathrm{mM}), \mathrm{Zn}(5 \mathrm{mM})$ or $\mathrm{Hg}(0.1 \mathrm{mM})$. Bacterial isolates $(n=150)$ from each soil set were selected as sensitive controls of the MIC determination analysis for the TEoEC and Ab. A $99 \mu \mathrm{L}$ aliquot of liquid culture adjusted to cell density of $5 \times 10^{5} \mathrm{~mL}^{-1}$ was dispensed to each well of 96-well polystyrene microtiter plates [38]. Cell density adjustment is discussed in Section S3. A $1 \mu \mathrm{L}$ aliquot of TEoEC or Ab stock was added to the wells in triplicates. Preparation of TEoEC and Ab stock solutions is described in Section S4. An aliquot of $1 \mu \mathrm{L}$ DMSO/99 $\mu \mathrm{L}$ fresh broth media, positive (growth without any antimicrobial additives) and negative (sterile; fresh media without bacterial cells) controls were included in triplicates. Staphylococcus aureus NCTS 12973, a standard Ab sensitive control strain was added to each batch. Cultures were incubated in a shaking incubator at $25^{\circ} \mathrm{C}$ and $200 \mathrm{rpm}$ for $72 \mathrm{~h} \mathrm{[39]} \mathrm{and} \mathrm{read} \mathrm{at} \mathrm{time} 0$ and 6-h intervals at $600 \mathrm{~nm}$ wavelength [40]. Bacterial resistance was quantified as MIC, based on data at the exponential growth phase, and was analysed according to the EUCAST ECOFF (epidemiological cut-off) recommendations. Antibiotic resistance in soil bacteria is defined as growth at $20 \mu \mathrm{g} \mathrm{mL}^{-1}$ as per the EUCAST ECOFF classification [37]. EC50 values were calculated for each batch of results using Prism-GraphPad 6 software and the Log (inhibitor) vs. response, variable slope (four parameters) method. Growth monitoring by plate culturing and measurements of the metals' bioavailability was carried out after $72 \mathrm{~h}$ incubation (Sections S5 and S6).

\subsection{Pollution Induced Community Tolerance (PICT) Analysis}

The tolerance of the bacterial consortia (cultures containing a diverse range of species) derived from soil samples to a range of antimicrobial agents at various concentrations was determined by a 96-well microtitre plate culture method called PICT [41]. A $100 \mu \mathrm{L}$ aliquot of culture dilution with $\sim 5 \times 10^{5} \mathrm{~mL}^{-1}$ bacterial cells was added to each well of microtitre plates containing $99 \mu \mathrm{L}$ of $2 \times \mathrm{R} 2 \mathrm{~A}$ broth [38] (Section S3). A $1 \mu \mathrm{L}$ aliquot of TEoEC or $\mathrm{Ab}$ was added to the allocated wells in triplicate, as were negative and positive controls (Section S4). The exponential growth rate of bacteria at 12-h incubation was recorded and used to calculate MICs. Growth monitoring (Section S5) and TEoEC bioavailability (Section S6) assessments were performed after $72 \mathrm{~h}$ incubation at $25^{\circ} \mathrm{C}$ and $200 \mathrm{rpm}$. 


\subsection{Terminal Restriction Fragment Length Polymorphism (TRFLP)}

Genomic DNA from the soil samples was extracted using Mo Bio PowerSoil ${ }^{\circledR}$ DNA Isolation Kits (Qiagen, Auckland) and subjected to TRFLP analysis to examine bacterial community diversity and structure. The $63 \mathrm{~F}$ forward primer $\left(5^{\prime}\right.$-CAG GCC TAA CAC ATG CAA GTC-3') 5'-labelled with 6-FAM ${ }^{\mathrm{TM}}$ [42] and the 1087R reverse primer (5'-CTC GTT GCG GGA CTT AAC CC-3') $5^{\prime}$-labelled with VIC ${ }^{\circledR}[43]$ were used to amplify $16 \mathrm{~S}$ rDNA. PCR conditions used are shown in Table S2. PCR amplimers were digested as previously described [44]. Restriction fragment lengths were measured by detection of terminal fluorescent labelled fragments analysed by ABI3730 Capillary Genetic Analyser [45]. TRFLP data analysis was performed with GeneMapper ${ }^{\circledR}$ v.4.1 for peak analysis and PRIMER v.7 software for analysis of relative abundance of terminal fragments as a proportion of a total peak height in that profile [46].

\subsection{Genetic Mobility of $C d$ Resistance by Horizontal Gene Transfer}

Two of the most common genes encoding $\mathrm{Cd}$ resistance in bacterial isolates, $\mathrm{cad} A$ and $c z c A$, were amplified as previously described [47] using the PCR conditions listed in Table S3. A total number of $135 \mathrm{Cd}$ resistant bacterial isolates (15 per soil sample) were tested for $c a d A$ and $c z c A$. Total bacterial genomic DNA was extracted by the boiling-cooling method [48]. An overnight broth culture of a streptomycin resistant (SmR) and Cd sensitive Pseudomonas aeruginosa ICMP 6286 (International Collection of Microorganisms from Plants (ICMP), Landcare Research, New Zealand) (denoted MUW001) was used as a recipient strain [49]. Incubation was performed at $37^{\circ} \mathrm{C}$ for $18 \mathrm{~h}$ followed by $6 \mathrm{~h}$ of incubation at $48{ }^{\circ} \mathrm{C}$ [50]. A lawn culture of recipient cells on well-dried $\mathrm{BH}$ agar (containing $2 \%$ agar, $100 \mu \mathrm{g} \mathrm{mL}^{-1}$ of Sm sulphate, and $1 \mathrm{mM} \mathrm{CdCl}_{2}$ ) [51] was printed with donor cells using sterile velvet cloth in a replica plate mating and incubated for $24 \mathrm{~h}$ at $37^{\circ} \mathrm{C}$. The sensitivity of the donor bacterial strains to the concentration of $100 \mu \mathrm{g} \mathrm{mL}^{-1}$ of Sm was determined prior to mating. The presence of the horizontally transferred $c z c A$ and $\operatorname{cad} A$ genes in transconjugant strains was investigated with the PCR reactions described above. Transconjugants were tested for resistance to TEoEC by culturing on nutrient agar plates containing $1 \mathrm{mM}$ of $\mathrm{Cd}, 5 \mathrm{mM}$ of $\mathrm{Zn}$ or $0.1 \mathrm{mM}$ of $\mathrm{Hg}$, and to $\mathrm{Ab}$ by broth microdilution assay using Tc, $\mathrm{Cm}$, Ery, $\mathrm{Cb}$ and Amp. The isolates carrying the mobilizable $c a d A$ and $c z c A$ genes were identified by $16 \mathrm{~S}$ rDNA sequencing using unlabeled $63 \mathrm{~F}$ and $1087 \mathrm{R}$ primers, and the data were compared to the NCBI nucleotide database using blastn.

\subsection{Statistical Analysis}

Three-way ANOVA analysis of the bacterial counts from each soil and comparison of mean values using Bonferroni correction for multiple comparisons was performed. Soils set, land use, and TEoEC concentration were independent variables. Monthly mean temperature and rainfall during the sampling months, moisture content, $\mathrm{pH}$, total $\mathrm{C}$ and $\mathrm{N}$ content, and Olsen $P$ values were covariates.

Four-way ANOVA analysis was conducted for resistant bacterial counts of the soil samples on plates with TEoEC and Ab additives. Soil sets, soils history of usage, initial TEoEC concentrations of soils, and TEoEC or Ab concentrations in media were independent variables. The dependent variable was bacterial CFU. Monthly mean temperature and rainfall during the sampling months, soils moisture content, $\mathrm{pH}$ of soils, total $\mathrm{C}$ and $\mathrm{N}$ content of soils, and Olsen P values were co-variates.

Three-way ANOVA analysis was conducted for PICT and broth microdilution analysis of bacteria from the soil samples. Soil samples, history of soils usage, and concentrations of $\mathrm{TEoEC}$ and $\mathrm{Ab}$ in microtitre plates were independent variables. The dependent variable was MIC or EC50 value.

Three-way ANOVA was carried out for TRFLP analysis to compare the abundance of the T-RFs between samples. Soil samples, history of soils usage, and soils TEoEC concentrations were independent variables. The dependent variable was the number of T-RFs reads. 


\section{Results}

\subsection{Physicochemical Properties of Soil}

The soil samples collected for this project were analysed for inorganic and organic analytes and other physicochemical features (Table 2). Cd and $\mathrm{Zn}$ concentrations were significantly higher in pastoral soils (sites EW-69 and EW-135) compared to arable (sites EW-85 and EW-86) and indigenous forest (background) soil (site EW-73) $(p<0.05)$. Other physicochemical features of the soil sampling sites from which these three soil sample sets were collected are listed in Table S4.

Table 2. Waikato region soil sampling sites physicochemical information.

\begin{tabular}{cccccc}
\hline Site No. & $\begin{array}{c}\text { EW-73 } \\
\text { (Indigenous Forest) }\end{array}$ & $\begin{array}{c}\text { EW-85 } \\
\text { (Arable) }\end{array}$ & $\begin{array}{c}\text { EW-86 } \\
\text { (Arable) }\end{array}$ & $\begin{array}{c}\text { EW-69 } \\
\text { (Pasture) }\end{array}$ & $\begin{array}{c}\text { EW-135 } \\
\text { (Pasture) }\end{array}$ \\
\hline pH & 5.60 & 6.07 & 5.74 & 5.01 & 5.76 \\
Total C (\%) & 8.00 & 3.79 & 3.40 & 10.10 & 8.63 \\
Total N (\%) & 0.48 & 0.30 & 0.30 & 0.94 & 0.84 \\
C:N & 16.7 & 12.5 & 11.4 & 10.8 & 10.3 \\
Olsen P* & 6.00 & 110 & 89.0 & 54.0 & 73.0 \\
Cd * & 0.09 & 0.54 & 0.49 & 0.82 & 1.11 \\
$\mathrm{Hg}^{*}$ & 0.19 & 0.31 & 0.42 & 0.20 & 0.21 \\
$\mathrm{Zn}^{*}$ & 27.00 & 39.00 & 40.00 & 65.00 & 62.00 \\
$\mathrm{Fe}^{*}$ & 28,000 & 42,000 & 53,000 & 59,000 & 39,000 \\
$\mathrm{P}^{*}$ & 290 & 1850 & 1540 & 2300 & 2500 \\
\hline
\end{tabular}

${ }^{*} \mathrm{mg} \mathrm{kg}^{-1}$ of dry soil.

\subsection{Bacteriological Characterisation of Soil Samples}

Plate counts on R2A medium revealed that total CFU/g in pastoral and arable cropping soils were higher compared to the background site $(p<0.05)$ for each sample set (WRSS1, the first sampling date in February 2014; WRSS2, the second sampling date in August 2014; WRSS3, the third sampling date in June 2015) (WRSS1, Figure 1). There were no significant differences in total CFU in pasture, arable and background soils between sampling dates. (Figure S1).

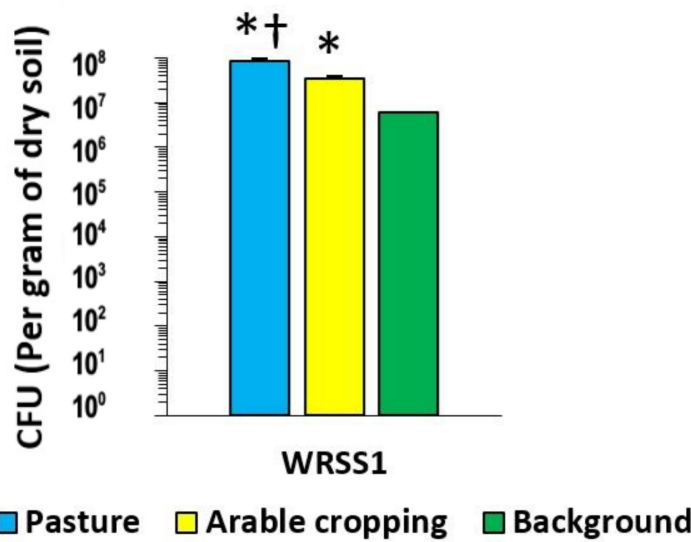

Figure 1. Total number of CFU (per gram of dry soil) from WRSS1 pastoral, arable and background soil samples, on R2A agar. ${ }^{*} p<0.05$ compared to background soil bacteria total CFU; $\uparrow p<0.05$ versus arable soil bacteria total CFU.

Plate culture of soil samples on R2A agar supplemented with three concentrations of $\mathrm{Cd}$ (Figure 2), Zn and Hg (Figure S2) showed that the ratios of TEoECR isolates/total CFU were higher for pastoral soil bacteria compared to those from background soil $(p<0.05)$. Ratios of TEoECR bacteria increased with decreasing TEoEC concentration. In terms of land use types, the highest ratios (most relative resistance) were found for pastoral soils, followed by arable soils, and then background. Similar results were determined for WRSS2 and WRSS3 (Figure S3). There were no significant differences between the ratios of TEoECR/total bacterial CFU between WRSS1, WRSS2 and WRSS3 collected on different 
dates. Overall, pastoral sites, with higher soil TEoEC levels, had higher ratios compared to arable and background sites on each sampling date.

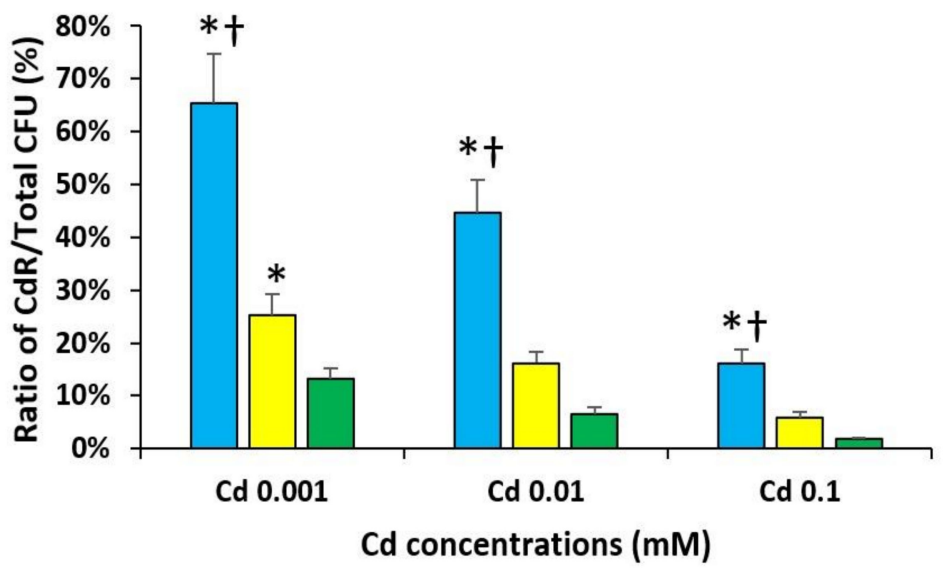

\section{$\square$ Pasture $\square$ Arable cropping $\square$ Background}

Figure 2. Mean ratios of TEoECR/total bacterial CFU (per gram of dry soil), selected on a range of $\mathrm{Cd}$ concentrations, for the three soil samples collected. ${ }^{*} p<0.05$ versus background; $+p<0.05$ versus arable.

Determination of AbR CFUs with plate counts from the soil samples allowed the calculation of ratios of AbR/total bacterial CFU of the WRSS1 pasture, arable and background (EW-73) soil samples when exposed to five common antibiotics (Tc (Figure 3), Cm, Ery, $\mathrm{Cb}$ and Amp (Figure S4). Pastoral and arable soils had significantly higher ratios of $\mathrm{AbR} /$ total bacterial CFU compared to background, and the pastoral soil had higher $\mathrm{AbR} /$ total bacterial CFU ratios compared to arable soil (Figure 3). Similar results were determined for WRSS2 and WRSS3 (Figure S5).

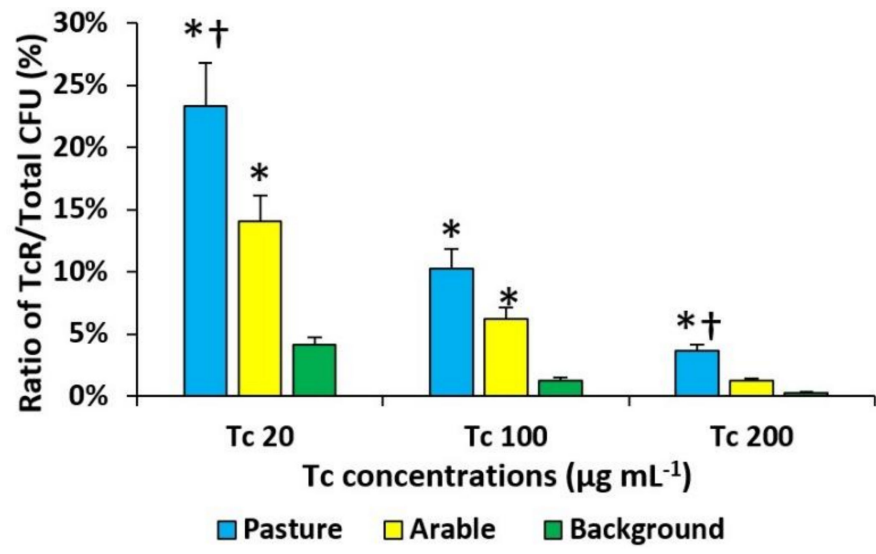

Figure 3. Mean ratios of AbR/total bacterial CFUs, on a range of Tc concentrations, for WRSS1. * $p<0.05$ versus background; $\uparrow p<0.05$ versus arable.

\subsection{Pollution Induced Community Tolerance (PICT) Assay}

Samples of bacterial consortia isolated from the soil sample sets were subjected to PICT analysis for Cd (Figure 4), Zn and Hg (Figure S6) for WRSS1 and indicated MIC and EC50 values were significantly greater for TEoEC for consortia from pastoral soil compared to those from background soil. 


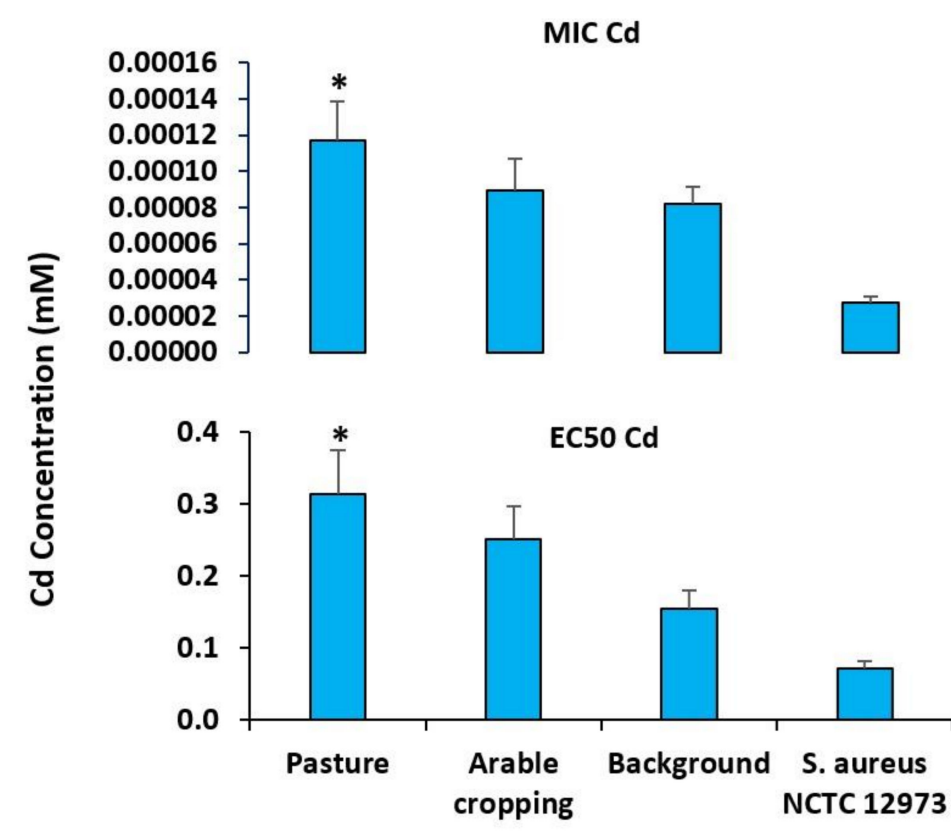

Bacteria from WRSS1

Figure 4. Mean MIC and EC50 values of PICT assay with Cd for bacteria from WRSS1. ${ }^{*} p<0.05$ compared to Cd MIC or EC50 values for bacteria from background soil.

In addition, PICT analysis of MICs of bacterial consortia isolated from WRSS1 for Tc (Figure 5), Cm, Ery, Cb and Amp (Figure S7) revealed larger MIC and EC50 values for antibiotics for bacterial consortia from pastoral and arable soils, compared to those from background soil. Very similar results were obtained for consortia from the WRSS2 and WRSS3 soil sample sets (Figures S8-S11).

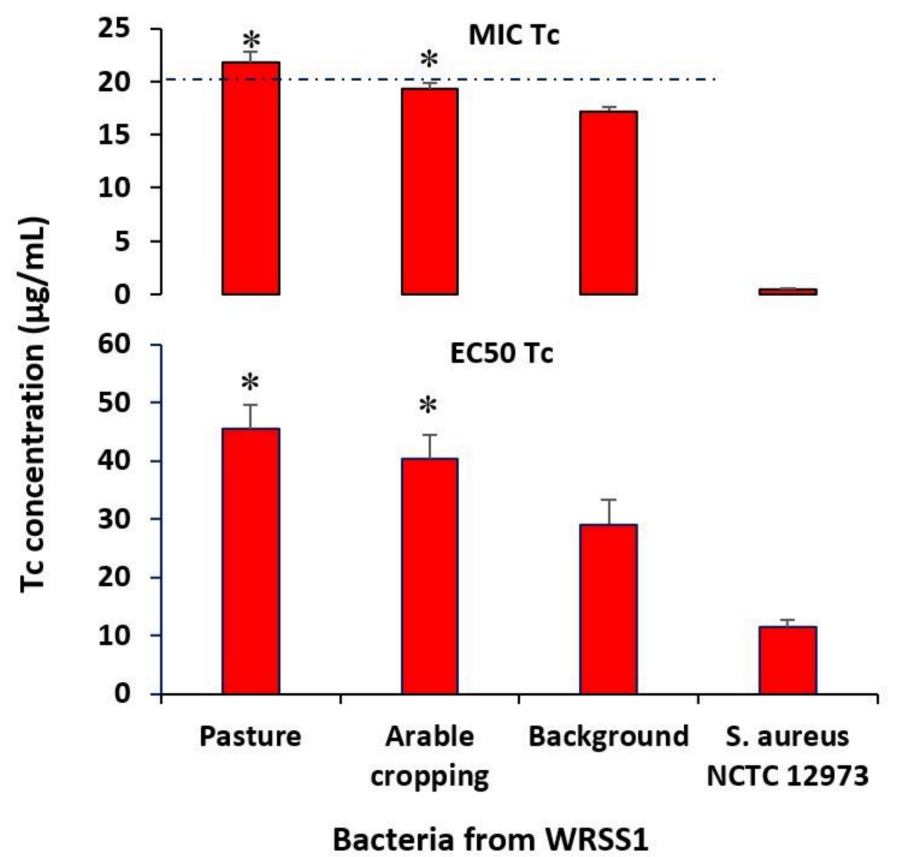

Figure 5. Mean MIC and EC50 values of PICT assay with Tc for bacteria from WRSS1. ${ }^{*} p<0.05$ compared to MIC or EC50 values from background soil. The dashed line defines the AbR level in soil bacteria. 


\subsection{Characterisation of Resistant Isolates}

Resistance levels of representative isolates from the WRSS1 sample set were determined by broth microdilution assay. Greater MIC and EC50 values for $\mathrm{Cd}$ (Figure 6), $\mathrm{Zn}$ and $\mathrm{Hg}$ (Figure S12), and for Tc (Figure 7), Cm, Ery, Cb and Amp (Figures S13 and S14) for the TEoECR bacteria from the pastoral and arable soil isolates were found compared to those from background soil. There were higher MIC and EC50 values for the TEoEC and $\mathrm{Ab}$ for TEoECR isolates from WRSS1 pastoral, arable cropping and background compared to TEoEC sensitive isolates from these soil samples. Furthermore, the mean MIC and EC50 values for all five $\mathrm{Ab}$ for the TEoECR isolates from WRSS1 pastoral, arable and background soils were greater than those for the TEoEC-sensitive isolates from each WRSS1 soil sample $(p<0.05)$. Similar results were obtained for bacteria from the WRSS2 and WRSS3 soil sample sets for the TEoEC and $\mathrm{Ab}$ (Figures S15-S22).
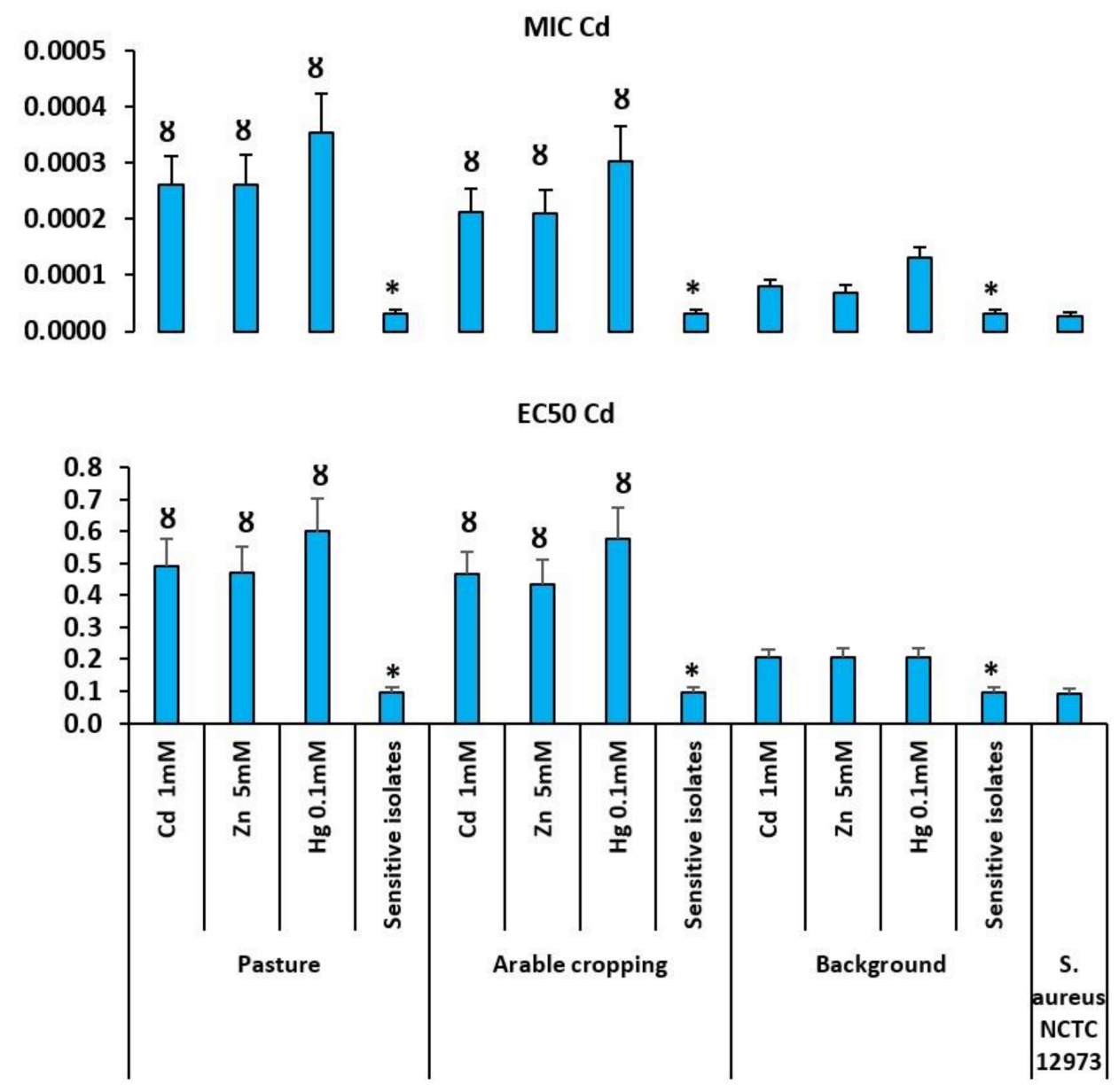

\section{Bacteria from WRSS1 on plates with concentration of $\mathrm{HM}(\mathrm{mM})$}

Figure 6. Mean MIC and EC50 values from broth microdilution assay with Cd for TEoECR isolates from WRSS1. ${ }^{*} p<0.05$ compared to value for TEoECR isolates from the same soil; $8 p<0.05$ compared to value for TEoECR isolates from background soil. 

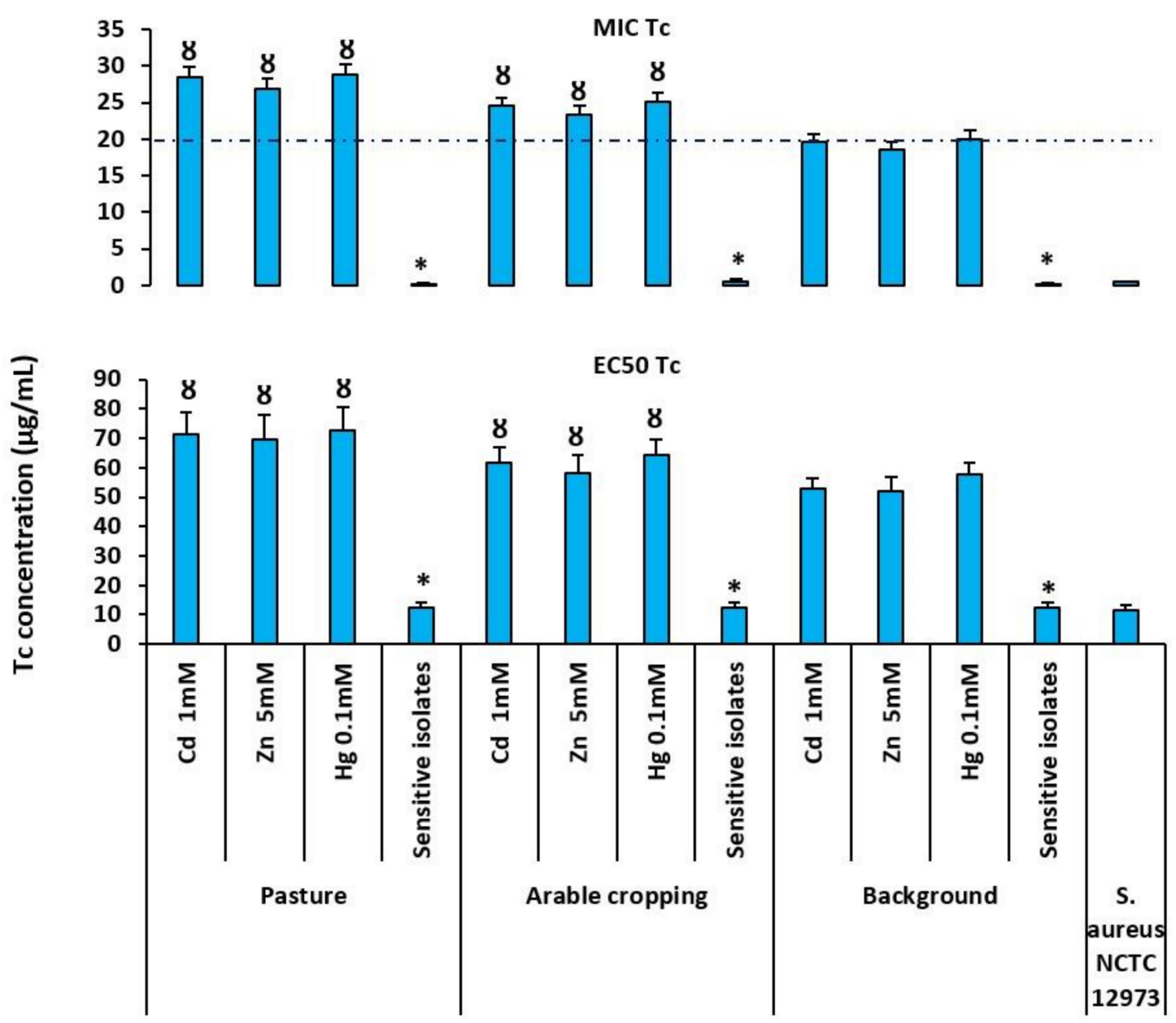

\section{Bacteria from WRSS1 on plates with concentration of HM (mM)}

Figure 7. Mean MIC and EC50 values for broth microdilution assay with Tc for TEoECR isolates from WRSS1. ${ }^{*} p<0.05$ compared to Tc MIC and EC50 values for TEoECR isolates from the same soil; $8 p<0.05$ compared to Tc MIC and EC50 values for isolates from background soil and selected on the same TEoEC concentration). The dashed line defines the Tc resistance level of soil bacteria.

\subsection{Bacterial Community Structure Investigation}

Community structures of bacteria in the soil samples sets were investigated by TRFLP analysis. The bacterial communities from pastoral soils shared $<80 \%$ similarity with those from arable and background soil. The profile of terminal restriction fragments in pastoral soils' bacterial communities was different from those for background and arable soils $(p<0.05)$ (Figure 8).

\subsection{Characterisation of $\mathrm{Cd}$ Resistance Genes}

A total of 19 bacterial isolates (14\%) from 135 selected $C d R$ isolates carried $c z c A$ and two isolates $(1.5 \%)$ carried $c a d A$. Table 3 lists the abundance of isolates carrying $c z c A$ and cadA genes amongst the CdR bacterial isolates tested.

Of the 21 bacterial isolates carrying $c a d A$ and/or $c z c A, 10$ were found to transfer these genes to the recipient MUW001 (Table 4). 


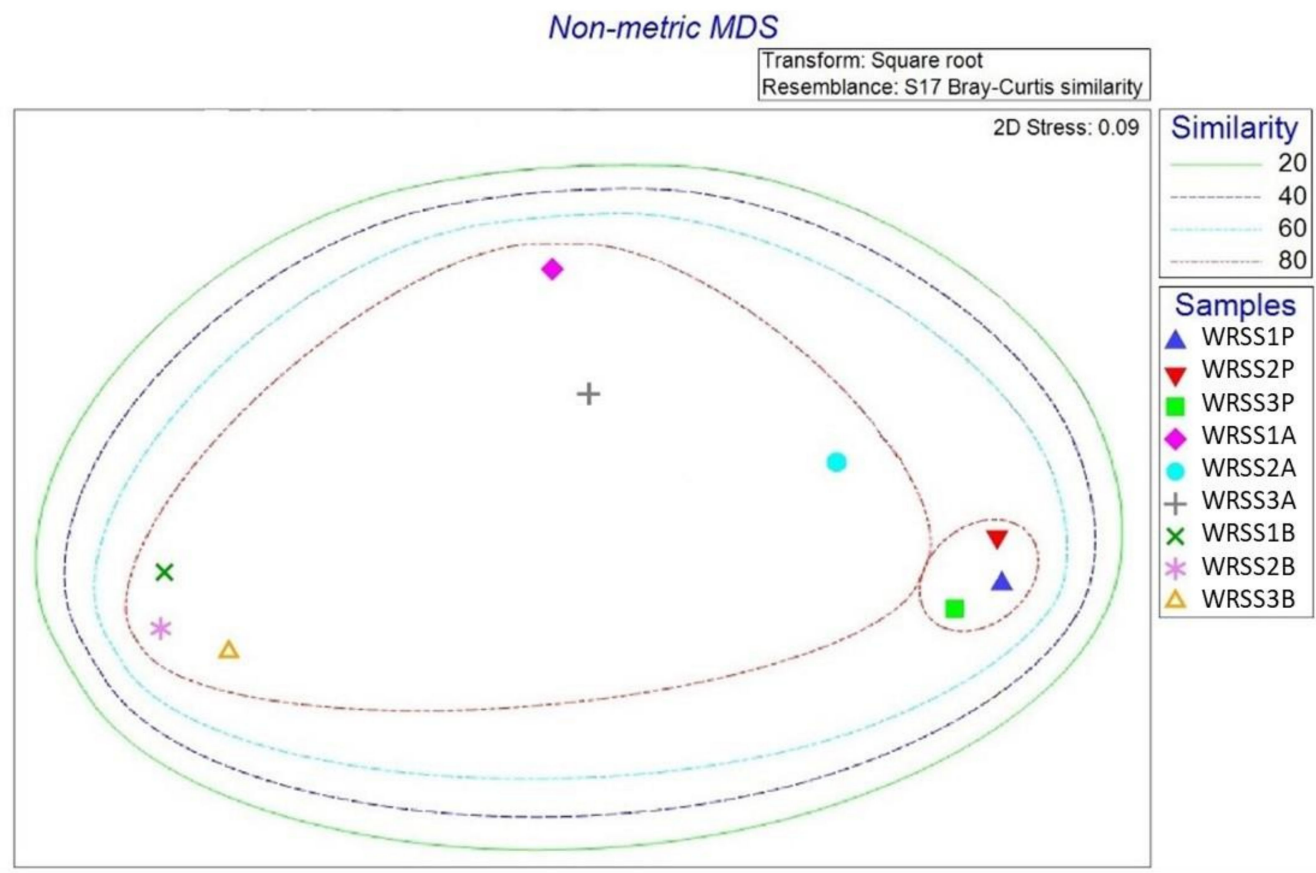

Figure 8. Non-metric multidimensional scaling analysis plot of TRFLP relative peak height for WR soils' bacterial communities' data, using the Bray-Curtis similarity index. Significant difference $(p<0.05)$ between the two clusters characterised with $>80 \%$ of similarity.

Table 3. Abundance of $c z c A$ and $c a d A$ genes amongst $C d R$ bacterial isolates.

\begin{tabular}{cccc}
\hline Soil Samples & Number of CdR Isolates & \multicolumn{2}{c}{ Cd Resistance Genes } \\
& & $c a d A$ & \multicolumn{1}{c}{$\boldsymbol{c} \boldsymbol{A}$} \\
\hline WRSS1 pasture & 15 & $1(6.6 \%)$ & $4(28.5 \%)$ \\
WRSS2 pasture & 15 & 0 & $3(20 \%)$ \\
WRSS3 pasture & 15 & 0 & $3(20 \%)$ \\
WRSS1 arable & 15 & 0 & $3(20 \%)$ \\
WRSS2 arable & 15 & 0 & $2(13.3 \%)$ \\
WRSS3 arable & 15 & 0 & $2(13.3 \%)$ \\
WRSS1 background & 15 & $1(6.6 \%)$ & $1(6.6 \%)$ \\
WRSS2 background & 15 & 0 & 0 \\
WRSS3 background & 15 & 0 & $1(6.6 \%)$ \\
\hline
\end{tabular}

Table 4. Mobilisation of $c a d A$ and $c z c A$ to recipient MUW001 by CdR isolates.

\begin{tabular}{ccc}
\hline Soil Samples & $\begin{array}{c}\text { Number of Transconjugants Carrying Cd Resistance Genes } \\
\text { cadA }\end{array}$ & $\begin{array}{c}c z \boldsymbol{A} \\
\text { WRSS1 pasture }\end{array}$ \\
WRSS2 pasture & 1 & 2 \\
WRSS3 pasture & 0 & 1 \\
WRSS1 arable & 0 & 2 \\
WRSS2 arable & 0 & 2 \\
WRSS3 arable & 0 & 1 \\
WRSS1 background & 0 & 0 \\
WRSS2 background & 1 & 0 \\
WRSS3 background & 0 & 0 \\
\hline
\end{tabular}

Transconjugants that received $c a d A$ or $c z c A$ were subjected to PCR validation. The $c a d A$ gene was amplified from both transconjugants that putatively received $c a d A$, and $c z c A$ was amplified from all the recipients that received the $c z c A$ gene $(n=8)$.

Plate culturing showed both the transconjugants that received $\operatorname{cad} A$ were resistant to $1 \mathrm{mM} \mathrm{Cd}$ and $5 \mathrm{mM} \mathrm{Zn}$, and one was resistant to $0.1 \mathrm{mM} \mathrm{Hg}$. While one transconjugant 
showed resistance to Tc and $\mathrm{Cm}$, both were resistant to Ery, $\mathrm{Cb}$ and Amp. Furthermore, all $c z c A+$ transconjugants were resistant to $1 \mathrm{mM} \mathrm{Cd}$ and $5 \mathrm{mM} \mathrm{Zn}$, and $75 \%$ of them showed resistance to $0.1 \mathrm{mM} \mathrm{Hg}$ (Figure 9). AbR profiles for the MUW001 $c z c A+$ transconjugants and $c a d A+$ transconjugants are shown in Figure 9.

A

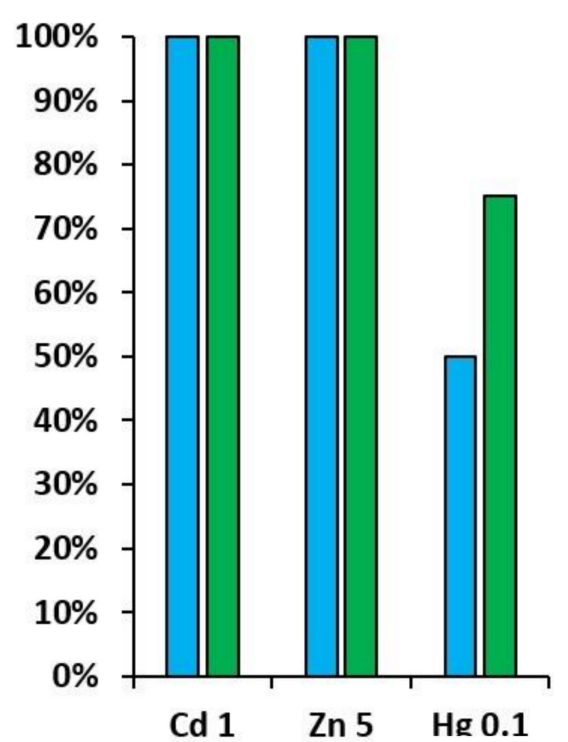

B

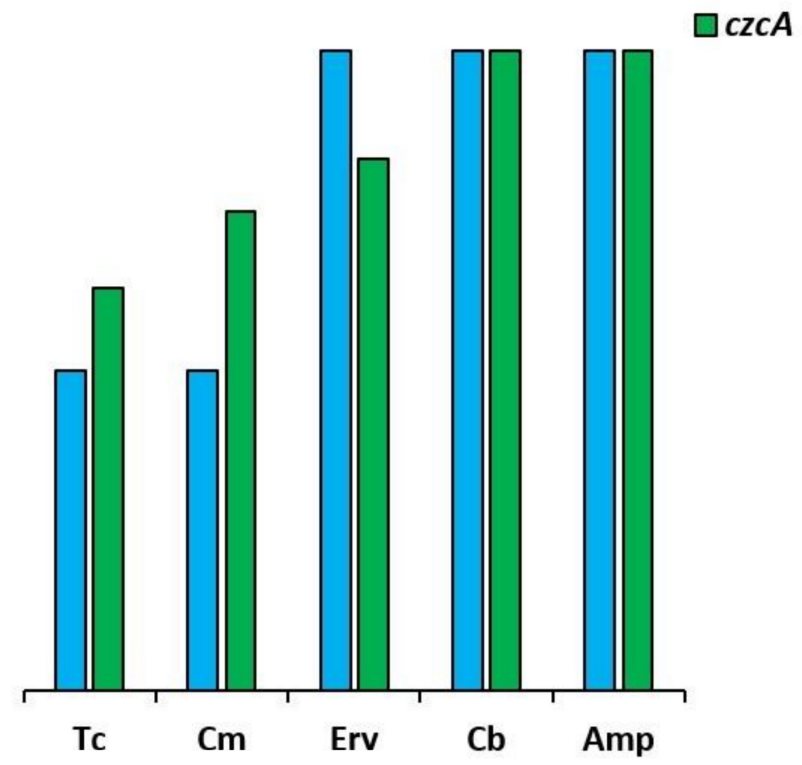

Antimicrobial Screening Conditions

Concentrations of $\mathrm{HM}(\mathrm{mM})$ and $\mathrm{Ab}\left(20 \mu \mathrm{gL} \mathrm{L}^{-1}\right)$

Figure 9. Percentage of transconjugant MUW001 carrying $c z c A$ and $c a d A$ genes resistant to (A) TEoEC (Cd $1 \mathrm{mM}, \mathrm{Zn} 5 \mathrm{mM}, \mathrm{Hg} 0.1 \mathrm{mM})$ and (B) Ab (20 ug/mL).

The donor strains with mobilisable $\mathrm{Cd}$ resistance genes were identified by $16 \mathrm{~S}$ rDNA sequencing. Table 5 lists identity of these isolates which were from the genera Rhodococcus, Pseudomonas, Chryseobacterium, Stenotrophomonas, Cupriavidus, Achromobacter, and Microbacterium.

Table 5. Individual bacterial isolates with mobilizable CdR identified by $16 \mathrm{~s}$ rDNA sequencing.

\begin{tabular}{|c|c|c|c|c|}
\hline Bacterial Isolate ID \& Source & Cd Resistance Gene & Description & Accession Number & Percent Identity \\
\hline MUW002 WRSS1, pasture & $\operatorname{cad} A$ & $\begin{array}{l}\text { Rhodococcus erythropolis partial 16S rRNA } \\
\text { gene, strain SBUG } 107 .\end{array}$ & FR745420.1 & $99.10 \%$ \\
\hline MUW003 WRSS1, pasture & $c z c A$ & $\begin{array}{l}\text { Pseudomonas azotoformans strain P45A } \\
\text { chromosome, complete genome. }\end{array}$ & СР041236.1 & $99.80 \%$ \\
\hline MUW004 WRSS1, pasture & $c z c A$ & $\begin{array}{l}\text { Chryseobacterium rhizosphaerae strain WTB5 } \\
\text { 16S ribosomal RNA gene, partial sequence. }\end{array}$ & MK240433.1 & $98.90 \%$ \\
\hline MUW005 WRSS2, pasture & $c z c A$ & $\begin{array}{l}\text { Stenotrophomonas maltophilia strain } \mathrm{Tj} 16 \mathrm{~S} \\
\text { ribosomal RNA gene, partial sequence. }\end{array}$ & MF280131.1 & $99.40 \%$ \\
\hline MUW006 WRSS3, pasture & $c z c A$ & $\begin{array}{l}\text { Bacterium strain BS1294 16S ribosomal } \\
\text { RNA gene, partial sequence. }\end{array}$ & MK824482.1 & $97.73 \%$ \\
\hline MUW007 WRSS3, pasture & $c z c A$ & $\begin{array}{l}\text { Chryseobacterium lactis partial 16S rRNA } \\
\text { gene, strain R-52618. }\end{array}$ & LN995695.1 & $99.20 \%$ \\
\hline MUW008 WRSS1, arable & $c z c A$ & $\begin{array}{l}\text { Bacterium strain BS1294 16S ribosomal } \\
\text { RNA gene, partial sequence. }\end{array}$ & MK824482.1 & $99.32 \%$ \\
\hline MUW009 WRSS1, arable & $c z c A$ & $\begin{array}{c}\text { Cupriavidus sp. strain JS3054 16S ribosomal } \\
\text { RNA gene, partial sequence. }\end{array}$ & MH588163.1 & $99.40 \%$ \\
\hline MUW010 WRSS2, arable & $c z c A$ & $\begin{array}{c}\text { Achromobacter xylosoxidans strain E2 16S } \\
\text { ribosomal RNA gene, partial sequence. } \\
\text { Microbacterium sp. strain }\end{array}$ & MK849863.1 & $99.20 \%$ \\
\hline MUW011 WRSS1, background & $\operatorname{cad} A$ & $\begin{array}{l}\text { PHIL_400ppmZn_ML16 16S ribosomal } \\
\text { RNA gene, partial sequence. }\end{array}$ & MK652511.1 & $99.59 \%$ \\
\hline
\end{tabular}

\section{Discussion}

Analysis of physicochemical properties of the soil samples collected from the pastoral and arable cropping farms and the background site confirmed that for major variables, the three sites were largely similar. This was as intended, as they were selected as nearby 
sites with the same soil type, but different land uses. Levels of organic matter, total P and trace elements reflected the histories of land management practices on the three properties since European settlement. It is acknowledged that samples from the background site do not constitute a true control for the pastoral and arable sites, but represent a practical alternative, as no site in the region with similar soil type had been farmed and not amended with superphosphate for any length of time.

Most Cd in New Zealand's pastoral soils came from superphosphate fertiliser. Historically, this fertiliser was derived from Nauru phosphate rock, which had high concentrations of $\mathrm{Cd}\left(\sim 550 \mathrm{mg} \mathrm{Cd} \mathrm{kg}^{-1}\right.$ of P). Cd contamination of soils was a potential problem and this resulted in the formation of the Cadmium Working Group administered by the New Zealand Fertiliser Quality Council. Starting in 1995, the New Zealand fertiliser industry introduced voluntary limits for the level of Cd in fertiliser. Initially, a level of $340 \mathrm{mg} \mathrm{Cd} \mathrm{kg}^{-1} \mathrm{P}$ between July 1995-December 1996 was used, limit levels incrementally reduced to an upper limit of $280 \mathrm{mg} \mathrm{Cd} \mathrm{kg}^{-1} \mathrm{P}$ from Jan 1997 onwards [52]. To avoid the accumulation of Cd in soil, phosphate fertilizers would need to contain less than $50 \mathrm{mg} \mathrm{Cd} / \mathrm{kg} \mathrm{P} \mathrm{[23].}$

The concentration of TEoEC including $\mathrm{Cd}$ and $\mathrm{Zn}$ in this study trended higher from background soils to arable to pastoral soils. In pastoral soils, superphosphate fertiliser application has elevated P, S, Ca, Cd and F levels in soil; and several Zn-containing agrichemicals (e.g., facial eczema remedies for curing sporodesmin toxicity) have contributed to an elevated $\mathrm{Zn}$ content $[29,30]$. In arable soils the main sources of $\mathrm{Cd}$ and $\mathrm{Zn}$ are superphosphate and ammonium phosphate fertilisers, and Zn-containing thiocarbamate fungicide sprays, respectively. Ab concentrations in the soil samples were not determined, but would be expected to be low and largely generated by microbial activity, due to the accepted practice of segregating animals treated with antibiotics [53]. Direct application of antibiotics to crops on arable farms is not standard practice. Measurements of antibiotics concentrations in soil show them to be highly variable [54]. While soil temperature and water content at the sampling sites vary with season, soil $\mathrm{pH}$ was not significantly different.

Culture, PICT and other techniques, showed that elevated TEoEC in soils was associated with increased TEoECR. In addition, we also showed that TEoEC were significantly linked to AbR. There were no significant differences between bacterial numbers in WRSS1 compared to the other two sets, except between the arable soils from WRSS1 and WRSS2 (sites EW85 and EW86). However, there were higher ratios of TEoECR:total CFU from pastoral soils compared to arable and background soils. Hermans et.al. (2017) [55], and Fierer and Jackson (2005) [56], reported that variation in soil environment has a more substantial effect on soil bacterial communities than climate changes. It has been suggested that soil moisture content and $\mathrm{pH}$ are likely the main factors affecting bacterial community structures [57], and that different levels of metal contaminations in soils affect bacterial diversity [58]. The long-term usage of $\mathrm{Cd}$ and $\mathrm{Zn}$-contained compounds has increased levels of TEoEC in soil. Bacterial resistance or tolerance to $\mathrm{Cd}$ may well result in higher levels of resistance to $\mathrm{Zn}$ and $\mathrm{Hg}$ as well, due to pleiotropic mutations and/or resistance genes encoding proteins involved in resistance to multiple metals (e.g., $c z c$ encoding cellular efflux pumps for $\mathrm{Cd}, \mathrm{Zn}$ and $\mathrm{Co}$ ) [59]. There were more $\mathrm{Hg}$ resistant bacteria in pastoral soils compared to those from arable and background soil, although there were no significant differences in the levels of $\mathrm{Hg}$ in pastoral soils compared to background soil; and $\mathrm{Hg}$ levels, in fact, were highest in arable soils. The low levels of $\mathrm{Hg}$ in NZ soils derive mainly from natural sources, particularly volcanism. We hypothesize that the higher level of bacterial resistance to $\mathrm{Hg}$ in pastoral soils compared to arable, is due to the higher levels of $\mathrm{Cd}$ and $\mathrm{Zn}$ [4]. Repetition of the pattern of the relative resistance following the order pastoral > arable $>$ background is interesting, because in the case of $\mathrm{Hg}$, levels in all soil samples were within their normal background ranges and there is no evidence for enrichment of $\mathrm{Hg}$ in farmed soils in New Zealand [60].

Plate culturing of bacteria isolated from soil samples showed higher levels of bacterial $\mathrm{AbR}$ in pastoral soils compared to arable and background soils. This suggests that the higher levels of $\mathrm{Cd}$ and $\mathrm{Zn}$ in pastoral soils and the higher levels of resistance to these 
TEoEC can induce the co-selection of resistance to these $\mathrm{Ab}$. This observation is similar to previous reports $[61,62]$ indicating that co-resistance may have arisen due to common mechanisms such as enhanced efflux or coregulation of resistance genes, and it is recognised that other contaminants may also select for AbR [12].

The PICT assays of bacterial communities from the soil samples revealed greater MIC and EC50 values for TEoEC and Ab in the pastoral soils' consortia compared to those from background soil. The MIC values determined for bacterial consortia from pastoral soil were higher than the $20 \mu \mathrm{g} \mathrm{mL}^{-1}$ threshold, while MICs were lower than this threshold for bacteria from arable soil for Tc, and also for background soil for Tc and Cm. It has been reported that higher levels of TEoEC in soils, leads to greater resistance to TEoEC amongst bacterial isolates $[63,64]$ The results of this study also found significant links between TEoECR and AbR. This resistance for $\mathrm{Ab}$ can occur in bacterial isolates with different levels of TEoECR. The introduction of resistant strains from stock manure is not thought to be involved, as animals treated with antibiotics are isolated. The MICs for Ab for the bacterial isolates from the pastoral and arable soils were higher than those of isolates from background soil. The higher MIC and EC50 values determined for pastoral and arable soils compared to background soils reflected the effects of higher levels of TEoEC in these soils and likely induced $\mathrm{Ab}$ resistance in the bacterial isolates from these soils [11].

MIC and EC50 values for TEoEC determined by broth microdilution assays for TEoECR isolates showed that individual isolates from pastoral and arable soils, which contain higher levels of TEoEC, were on average more resistant to the TEoEC than isolates from background soil. The levels of $\mathrm{Ab}$ resistance in TEoECR isolates were likely higher due to co-selection for AbR. This may occur due to various mechanisms (e.g., co-location of resistance genes) [25]. Henriques et. al., 2016 [65], suggest that the levels of Ab resistance in bacteria are significantly related to the levels of TEoEC in the environment. The higher levels of $\mathrm{Cd}$ and $\mathrm{Zn}$ in pastoral soils explain the subsequent co-selection of $\mathrm{Ab}$ resistance along with TEoEC resistance, as in recent reports [24]. Greater MIC and EC50 values for bacteria from the pastoral and arable soils compared to those from background soil showed higher levels of TEoEC resistance and AbR in bacteria. In a previous publication [66], the percentage of bacteria categorised as AbR amongst TEoECR isolates was significantly higher than the TEoEC-sensitive bacteria, which supports the phenomenon of TEoEC and Ab co-resistance.

TRFLP analysis of bacterial 16s rDNA gene profiles was used to compare soil microbial community structures TEoEC present in soil alters bacterial community structures [67]. TRFLP analysis on the soil samples revealed that higher levels of TEoEC in pastoral compared to background and arable soils were associated with distinct bacterial community structures suggesting the selection of particular species in the presence of high levels of TEoEC. High levels of TEoEC in pastoral and arable soils were a selective influence on many bacterial taxa [68]. We found relatively distinct clusters of terminal restriction fragments'abundance in pastoral samples compared to background and arable samples (Figure 8) in concordance with Brodie et. al. (2002) [69].

HGT through bacterial mobile genetic elements is an important mode of spread of TEoECR and AbR genes [70]. The cadA gene is carried either on plasmids [71] or chromosomes and encodes a $\mathrm{Cd}^{+2}$-ATPase protein transporter [47], also conferring $\mathrm{Zn}$ resistance [72]. We found only Gram-positive isolates including Rhodococcus sp. and a member of the Gram-variable Micobacterium genus amplified cadA as reported by others [73]. The $c z c A$ gene encodes a domain of efflux-RND proteins engaged in $\mathrm{Zn}^{2+}, \mathrm{Co}^{2+}$, and $\mathrm{Cd}^{2+}$ efflux [74]. The most abundant bacterial phyla carrying $c z c A$ are Proteobacteria (e.g., Pseudomonas and Cupriavidus), Actinobacteria, Verrucomicrobia, and Bacteroidetes (mainly Chryseobacterium) [75,76], in accordance with our findings. It has been suggested that the occurrence of $c a d A$ and $c z c A$ in soil bacteria can be selected by TEoEC contamination pressure [77]. Several of our CdR isolates could transfer czcA or cadA in conjugation assays and the transconjugants obtained were AbR at levels $>20 \mu \mathrm{g} \mathrm{mL}^{-1}$. 


\section{Conclusions}

In conclusion, this study showed that the abundance of the bacterial isolates resistant to TEoEC and $\mathrm{Ab}$ was greater in soils with higher levels of TEoEC, compared to those from soils with lower levels of TEoEC. AbR was strongly associated with soil with higher levels of TEoEC. Moreover, the structure of soil bacterial communities appeared changed under selective pressure associated with the presence of TEoEC. Cd resistance genes, in CdR bacterial isolates, were mobile and introduced co-resistance to a range of $\mathrm{Ab}$ to a laboratory strain, demonstrating the potential for resistance genes selected by TEoEC contamination to spread to human and animal pathogens.

Supplementary Materials: The following are available online at https:/ /www.mdpi.com/article/ 10.3390/su14031790/s1, Sections S1-S6, Tables S1-S4, Figures S1-S22.

Author Contributions: Conceptualization, N.D.K. and B.R.P.; Data curation, A.H.; Formal analysis, A.H., N.D.K., A.S. and B.R.P.; Funding acquisition, N.D.K. and B.R.P.; Investigation, A.H.; Methodology, A.H., N.D.K., J.H., G.G., A.S., M.T., C.B. and B.R.P.; Project administration, N.D.K. and B.R.P.; Resources, N.D.K., J.H., A.S. and M.T.; Software, J.H.; Supervision, N.D.K., J.H., G.G., A.S., C.B. and B.R.P.; Visualization, A.H.; Writing—original draft, A.H., N.D.K. and B.R.P.; Writing—review \& editing, A.H., N.D.K., J.H., G.G., A.S., M.T., C.B. and B.R.P. All authors have read and agreed to the published version of the manuscript.

Funding: This research was funded by Massey University Research Funding (MURF).

Institutional Review Board Statement: Not applicable.

Informed Consent Statement: All authors have read and agreed to the published version of the manuscript.

Data Availability Statement: The data presented in this study are available on request from the corresponding author.

Acknowledgments: The authors would like to express their sincere gratitude to Jackie Aislabie, Landcare Research Institute, Hamilton, New Zealand for advice, and laboratory staff at School of Health Sciences, Massey University Wellington for their help facilitating laboratory investigations of this project.

Conflicts of Interest: The authors declare no conflict of interest.

\section{References}

1. Teitzel, G.M.; Parsek, M.R. Heavy metal resistance of biofilm and planktonic Pseudomonas aeruginosa. Appl. Environ. Microbiol. 2003, 69, 2313-2320. [CrossRef] [PubMed]

2. Silver, S. Bacterial resistances to toxic metal ions-A review. Gene 1996, 179, 9-19. [CrossRef]

3. Lemire, J.A.; Harrison, J.J.; Turner, R.J. Antimicrobial activity of metals: Mechanisms, molecular targets and applications. Nat. Rev. Microbiol. 2013, 11, 371-384. [CrossRef] [PubMed]

4. Harrison, J.J.; Ceri, H.; Turner, R.J. Multimetal resistance and tolerance in microbial biofilms. Nat. Rev. Microbiol. 2007, 5, 928-938. [CrossRef]

5. Seiler, C.; Berendonk, T.U. Heavy metal driven co-selection of antibiotic resistance in soil and water bodies impacted by agriculture and aquaculture. Front. Microbiol. 2012, 3, 399. [CrossRef]

6. Sutton, N.B.; Maphosa, F.; Morillo, J.A.; Abu Al-Soud, W.; Langenhoff, A.A.; Grotenhuis, T.; Rijnaarts, H.H.; Smidt, H. Impact of long-term diesel contamination on soil microbial community structure. Appl. Environ. Microbiol. 2013, 79, 619-630. [CrossRef]

7. Gullberg, E.; Albrecht, L.M.; Karlsson, C.; Sandegren, L.; Andersson, D.I. Selection of a multidrug resistance plasmid by sublethal levels of antibiotics and heavy metals. mBio 2014, 5, e01918-14. [CrossRef]

8. Baker-Austin, C.; Wright, M.S.; Stepanauskas, R.; McArthur, J.V. Co-selection of antibiotic and metal resistance. Trends Microbiol. 2006, 14, 176-182. [CrossRef]

9. Wales, A.D.; Davies, R.H. Co-Selection of Resistance to Antibiotics, Biocides and Heavy Metals, and Its Relevance to Foodborne Pathogens. Antibiotics 2015, 4, 567-604. [CrossRef]

10. Dickinson, A.W.; Power, A.; Hansen, M.G.; Brandt, K.K.; Piliposian, G.; Appleby, P.; O'Neill, P.A.; Jones, R.T.; Sierocinski, P.; Koskella, B.; et al. Heavy metal pollution and co-selection for antibiotic resistance: A microbial palaeontology approach. Environ. Int. 2019, 132, 105117. [CrossRef]

11. Chen, J.; Li, J.; Zhang, H.; Shi, W.; Liu, Y. Bacterial Heavy-Metal and Antibiotic Resistance Genes in a Copper Tailing Dam Area in Northern China. Front. Microbiol. 2019, 10, 1916. [CrossRef] 
12. Cen, T.; Zhang, X.; Xie, S.; Li, D. Preservatives accelerate the horizontal transfer of plasmid-mediated antimicrobial resistance genes via differential mechanisms. Environ. Int. 2020, 138, 105544. [CrossRef]

13. Spain, A.; Alm, E. Implications of microbial heavy metal tolerance in the environment. Rev. Undergrad. Res. 2003, 2, 1-6.

14. Al Salah, D.M.M.; Laffite, A.; Sivalingam, P.; Pote, J. Occurrence of toxic metals and their selective pressure for antibiotic-resistant clinically relevant bacteria and antibiotic-resistant genes in river receiving systems under tropical conditions. Environ. Sci. Pollut. Res. Int. 2021. [CrossRef]

15. Taylor, M.; Kim, N.; Smidt, G. Trace element contaminants and radioactivity from phosphate fertiliser. In Phosphorus in Agriculture: 100\% Zero; Schnug, E., De Kok, L.J., Eds.; Springer: Dordrecht, The Netherlands, 2016; pp. 231-266.

16. Council, W.R. Cadmium and New Zealand Agriculture and Horticulture: A Strategy for Long-Term Risk Management; Ministry of Agriculture and Forestry: Wellington, New Zealand, 2011.

17. Cavanagh, J. Working Towards New Zealand Risk-Based Soil Guideline Values for the Management of Cadmium Accumulation on Productive Land; Ministry for Primary Industries: Wellington, New Zealand, 2012.

18. Vermeulen, V. Use of Zinc in Agriculture: An Assessment of Data for Evidence of Accumulation in Waikato Soils Surface Water and Sediments. Master Thesis, Massey University, Wellington, New Zealand, 2015.

19. Alloway, B.J. Zinc in Soils and Crop Nutrition; International fertilizer Industry Association and International Zinc Association: Brussels, Belgium, 2004.

20. McDowell, R.W.; Taylor, M.D.; Stevenson, B.A. Natural background and anthropogenic contributions of cadmium to New Zealand soils. Agric. Ecosyst. Environ. 2013, 165, 80-87. [CrossRef]

21. Taylor, M.; Gibb, R.; Willoughby, J.; Hewitt, A.; Arnold, G. Soil Maps of Cadmium in New Zealand; Manaaki Whenua-Landcare Research: Wellington, New Zealand, 2007.

22. Alloway, B.J. Copper and Zinc in soils: Too little or too much. In Proceedings of the New Zealand Trace Elements Group Conference, Hamilton, New Zealand, 13-15 February 2008; p. 10.

23. Kim, N.; Robinson, B. Cadmium: A clandestine threat to food safety. Food Qual. Saf. 2015, 22, 49-51.

24. Zhang, J.; Liu, J.; Lu, T.; Shen, P.; Zhong, H.; Tong, J.; Wei, Y. Fate of antibiotic resistance genes during anaerobic digestion of sewage sludge: Role of solids retention times in different configurations. Bioresour. Technol. 2019, 274, 488-495. [CrossRef]

25. Ma, X.; Guo, N.; Ren, S.; Wang, S.; Wang, Y. Response of antibiotic resistance to the co-existence of chloramphenicol and copper during bio-electrochemical treatment of antibiotic-containing wastewater. Environ. Int.. 2019, 126, 127-133. [CrossRef]

26. Soucy, S.M.; Huang, J.; Gogarten, J.P. Horizontal gene transfer: Building the web of life. Nat. Rev. Genet. 2015, 16, 472-482. [CrossRef]

27. Derakshani, M.; Lukow, T.; Liesack, W. Novel bacterial lineages at the (sub)division level as detected by signature nucleotidetargeted recovery of $16 \mathrm{~S}$ rRNA genes from bulk soil and rice roots of flooded rice microcosms. Appl. Environ. Microbiol. 2001, 67, 623-631. [CrossRef]

28. Dubé, J.S.; Boudreault, J.P.; Bost, R.; Sona, M.; Duhaime, F.; Éthier, Y. Representativeness of laboratory sampling procedures for the analysis of trace metals in soil. Environ. Sci. Pollut. Res. Int. 2015, 22, 11862-11876. [CrossRef]

29. Kim, N.D.; Taylor, M.D.; Drewry, J.J. Anthropogenic fluorine accumulation in the Waikato and Bay of Plenty regions of New Zealand: Comparison of field data with projections. Environ. Earth Sci. 2016, 75, 147. [CrossRef]

30. Kim, N.D. Cadmium Accumulation in Waikato Soils.; Waikato Regional Council: Hamilton, New Zealand, 2008.

31. Zealand, S.N. Nitrogen and Phosphorus in Fertilisers; Statistics New Zealand: Wellington, New Zealand, 2019.

32. Hewitt, A.E. New Zealand Soil Classification, 3rd ed.; Manaaki Whenua Press: Lincoln, New Zealand, $2010 ;$ p. 136.

33. IUSS Working Group WRB. World Reference Base for Soil Resources; Food and Agriculture Organization of the United Nations: Rome, Italy, 2015.

34. Mohamed, R.M.; Abo-Amer, A.E. Isolation and characterization of heavy-metal resistant microbes from roadside soil and phylloplane. J. Basic Microbiol. 2012, 52, 53-65. [CrossRef]

35. Craig Maclean, R. Adaptive radiation in microbial microcosms. J. Evolut. Biol. 2005, 18, 1376-1386. [CrossRef]

36. Nishioka, T.; Elsharkawy, M.M.; Suga, H.; Kageyama, K.; Hyakumachi, M.; Shimizu, M. Development of Culture Medium for the Isolation of Flavobacterium and Chryseobacterium from Rhizosphere Soil. Microbes Environ. 2016, 31, 104-110. [CrossRef]

37. EUCAST. MIC and Zone Diameter Distributions and Ecoffs. Available online: https://www.eucast.org/mic_distributions_and_ ecoffs / (accessed on 9 November 2021).

38. Müsken, M.; Di Fiore, S.; Römling, U.; Häussler, S. A 96-well-plate-based optical method for the quantitative and qualitative evaluation of Pseudomonas aeruginosa biofilm formation and its application to susceptibility testing. Nat. Protoc. 2010, 5, 1460. [CrossRef]

39. Ibekwe, A.M.; Papiernik, S.K.; Gan, J.; Yates, S.R.; Yang, C.H.; Crowley, D.E. Impact of fumigants on soil microbial communities. Appl. Environ. Microbiol. 2001, 67, 3245-3257. [CrossRef] [PubMed]

40. Chen, S.; Li, X.; Sun, G.; Zhang, Y.; Su, J.; Ye, J. Heavy Metal Induced Antibiotic Resistance in Bacterium LSJC7. Int. J. Mol. Sci. 2015, 16, 23390-23404. [CrossRef]

41. Rousk, J.; Rousk, K. Responses of microbial tolerance to heavy metals along a century-old metal ore pollution gradient in a subarctic birch forest. Environ. Pollut. 2018, 240, 297-305. [CrossRef] 
42. Marchesi, J.R.; Sato, T.; Weightman, A.J.; Martin, T.A.; Fry, J.C.; Hiom, S.J.; Dymock, D.; Wade, W.G. Design and evaluation of useful bacterium-specific PCR primers that amplify genes coding for bacterial 16S rRNA. Appl. Environ. Microbiol. 1998, 64, 795-799. [CrossRef]

43. Hauben, L.; Vauterin, L.; Swings, J.; Moore, E.R. Comparison of $16 \mathrm{~S}$ ribosomal DNA sequences of all Xanthomonas species. Int. J. Syst. Bacteriol. 1997, 47, 328-335. [CrossRef] [PubMed]

44. Horswell, J.; Prosser, J.A.; Siggins, A.; van Schaik, A.; Ying, L.; Ross, C.; McGill, A.; Northcott, G. Assessing the impacts of chemical cocktails on the soil ecosystem. Soil Biol. Biochem. 2014, 75, 64-72. [CrossRef]

45. Gielen, G.J.; Clinton, P.W.; Van den Heuvel, M.R.; Kimberley, M.O.; Greenfield, L.G. Influence of sewage and pharmaceuticals on soil microbial function. Environ. Toxicol. Chem. 2011, 30, 1086-1095. [CrossRef] [PubMed]

46. Marsh, T.L.; Saxman, P.; Cole, J.; Tiedje, J. Terminal restriction fragment length polymorphism analysis program, a web-based research tool for microbial community analysis. Appl. Environ. Microbiol. 2000, 66, 3616-3620. [CrossRef]

47. Oger, C.; Berthe, T.; Quillet, L.; Barray, S.; Chiffoleau, J.F.; Petit, F. Estimation of the abundance of the cadmium resistance gene cadA in microbial communities in polluted estuary water. Res. Microbiol. 2001, 152, 671-678. [CrossRef]

48. Ausubel, F.M. Short Protocols in Molecular Biology: A Compendium of Methods from Current Protocols in Molecular Biology; Wiley: New York, NY, USA, 2002.

49. Brophy, J.A.N.; Triassi, A.J.; Adams, B.L.; Renberg, R.L.; Stratis-Cullum, D.N.; Grossman, A.D.; Voigt, C.A. Engineered integrative and conjugative elements for efficient and inducible DNA transfer to undomesticated bacteria. Nat. Microbiol. 2018, 3, 1043-1053. [CrossRef]

50. Aviv, G.; Rahav, G.; Gal-Mor, O. Horizontal Transfer of the Salmonella enterica Serovar Infantis Resistance and Virulence Plasmid pESI to the Gut Microbiota of Warm-Blooded Hosts. mBio 2016, 7, e01395-16. [CrossRef]

51. Hung, C.W.; Martinez-Marquez, J.Y.; Javed, F.T.; Duncan, M.C. A simple and inexpensive quantitative technique for determining chemical sensitivity in Saccharomyces cerevisiae. Sci. Rep. 2018, 8, 11919. [CrossRef]

52. Rys, G. A Cadmium Management Strategy for New Zealand. In Proceedings of the Fertiliser and Lime Conference, Palmerston North, New Zealand, 11-13 November 2011; p. 14.

53. Association, N.Z.V. Antibiotic Judicious Use Guidelines for the New Zealand Veterinary Profession—Dairy; New Zealand Veterinary Association: Wellington, New Zealand, 2018.

54. Cycon, M.; Mrozik, A.; Piotrowska-Seget, Z. Antibiotics in the Soil Environment-Degradation and Their Impact on Microbial Activity and Diversity. Front. Microbiol. 2019, 10, 338. [CrossRef]

55. Hermans, S.M.; Buckley, H.L.; Case, B.S.; Curran-Cournane, F.; Taylor, M.; Lear, G. Bacteria as Emerging Indicators of Soil Condition. Appl. Environ. Microbiol. 2017, 83, e02826-16. [CrossRef]

56. Fierer, N.; Jackson, R.B. The diversity and biogeography of soil bacterial communities. Proc. Natl. Acad. Sci. USA 2006, 103, 626-631. [CrossRef]

57. Guo, D.; Fan, Z.; Lu, S.; Ma, Y.; Nie, X.; Tong, F.; Peng, X. Changes in rhizosphere bacterial communities during remediation of heavy metal-accumulating plants around the Xikuangshan mine in southern China. Sci. Rep. 2019, 9, 1947. [CrossRef]

58. Wang, N.; Zhang, S.; He, M. Bacterial community profile of contaminated soils in a typical antimony mining site. Environ. Sci. Pollut. Res. Int. 2018, 25, 141-152. [CrossRef]

59. Yu, Z.; Gunn, L.; Wall, P.; Fanning, S. Antimicrobial resistance and its association with tolerance to heavy metals in agriculture production. Food Microbiol. 2017, 64, 23-32. [CrossRef]

60. Taylor, M.D.; Kim, N. Dealumination as a mechanism for increased acid recoverable aluminium in Waikato mineral soils. Austral. J. Soil Res. 2009, 47, 828-838. [CrossRef]

61. Li, L.G.; Xia, Y.; Zhang, T. Co-occurrence of antibiotic and metal resistance genes revealed in complete genome collection. ISME J. 2017, 11, 651-662. [CrossRef]

62. Zhao, Y.; Cocerva, T.; Cox, S.; Tardif, S.; Su, J.Q.; Zhu, Y.G.; Brandt, K.K. Evidence for co-selection of antibiotic resistance genes and mobile genetic elements in metal polluted urban soils. Sci. Total Environ. 2019, 656, 512-520. [CrossRef]

63. Zhu, Y.; Zhang, W.; Schwarz, S.; Wang, C.; Liu, W.; Chen, F.; Luan, T.; Liu, S. Characterization of a blaIMP-4-carrying plasmid from Enterobacter cloacae of swine origin. J. Antimicrob. Chemother. 2019, 74, 1799-1806. [CrossRef]

64. Liu, B.; Li, Y.; Gao, S.; Chen, X. Copper exposure to soil under single and repeated application: Selection for the microbial community tolerance and effects on the dissipation of antibiotics. J. Hazard. Mater. 2017, 325, 129-135. [CrossRef] [PubMed]

65. Henriques, I.; Tacão, M.; Leite, L.; Fidalgo, C.; Araújo, S.; Oliveira, C.; Alves, A. Co-selection of antibiotic and metal(loid) resistance in gram-negative epiphytic bacteria from contaminated salt marshes. Mar. Pollut. Bull. 2016, 109, 427-434. [CrossRef]

66. Bhullar, K.; Waglechner, N.; Pawlowski, A.; Koteva, K.; Banks, E.D.; Johnston, M.D.; Barton, H.A.; Wright, G.D. Antibiotic resistance is prevalent in an isolated cave microbiome. PLoS ONE 2012, 7, e34953. [CrossRef] [PubMed]

67. Sandaa, R.A.; Enger, O.; Torsvik, V. Abundance and diversity of Archaea in heavy-metal-contaminated soils. Appl. Environ. Microbiol. 1999, 65, 3293-3297. [CrossRef] [PubMed]

68. Reith, F.; Zammit, C.M.; Pohrib, R.; Gregg, A.L.; Wakelin, S.A. Geogenic Factors as Drivers of Microbial Community Diversity in Soils Overlying Polymetallic Deposits. Appl. Environ. Microbiol. 2015, 81, 7822-7832. [CrossRef]

69. Brodie, E.; Edwards, S.; Clipson, N. Bacterial community dynamics across a floristic gradient in a temperate upland grassland ecosystem. Microb. Ecol. 2002, 44, 260-270. [CrossRef] 
70. Lu, X.M.; Lu, P.Z. Distribution of antibiotic resistance genes in soil amended using Azolla imbricata and its driving mechanisms. Sci. Total Environ. 2019, 692, 422-431. [CrossRef]

71. Udo, E.E.; Jacob, L.E.; Mathew, B. A cadmium resistance plasmid, pXU5, in Staphylococcus aureus, strain ATCC25923. FEMS Microbiol. Lett. 2000, 189, 79-80. [CrossRef]

72. Silver, S.; Phung, L.T. Bacterial heavy metal resistance: New surprises. Annu. Rev. Microbiol. 1996, 50, 753-789. [CrossRef]

73. Fu, L.M.; Fu-Liu, C.S. Is Mycobacterium tuberculosis a closer relative to Gram-positive or Gram-negative bacterial pathogens? Tuberculosis 2002, 82, 85-90. [CrossRef]

74. Nies, D.H. Efflux-mediated heavy metal resistance in prokaryotes. FEMS Microbiol. Rev. 2003, 27, 313-339. [CrossRef]

75. Li, X.; Yan, Z.; Gu, D.; Li, D.; Tao, Y.; Zhang, D.; Su, L.; Ao, Y. Characterization of cadmium-resistant rhizobacteria and their promotion effects on Brassica napus growth and cadmium uptake. J. Basic Microbiol. 2019, 59, 579-590. [CrossRef]

76. Karelová, E.; Harichová, J.; Stojnev, T.; Pangallo, D.; Ferianc, P. The isolation of heavy-metal resistant culturable bacteria and resistance determinants from a heavy-metal-contaminated site. Biologia 2011, 66, 18-26. [CrossRef]

77. Kaci, A.; Petit, F.; Lesueur, P.; Boust, D.; Vrel, A.; Berthe, T. Distinct diversity of the czcA gene in two sedimentary horizons from a contaminated estuarine core. Environ. Sci. Pollut. Res. Int. 2014, 21, 10787-10802. [CrossRef] [PubMed] 